\title{
【特＼cjkstart集】前立腺癌の診断と治療一最近の注目事項を中心に一
}

$$
\text { 5. 会員制クリニックにおける前立腺癌検診の実際 }
$$

日本医科大学泌尿器科 ${ }^{1)}$, 東京医科大学泌尿器科 2 , 水町クリニック ${ }^{3)}$, 西安交通大学泌尿器科4)

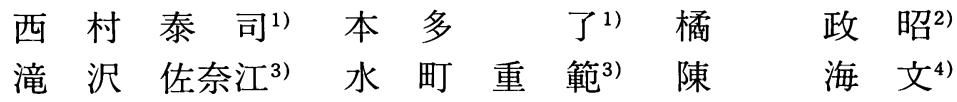

\section{Examination for Prostate Cancer in Routine Annual Health Examination in a Membership Clinic}

Taiji NISHIMURA ${ }^{1)}$, Ryo HONDA ${ }^{1)}$, Masaaki TACHIBANA ${ }^{2)}$, Sanae TAKIZAWA ${ }^{3)}$, Shigenori MIZUMACHI ${ }^{3)}$ and Haiwen $\mathrm{CHEN}^{4)}$

\author{
${ }^{1)}$ Department of Urology, Nippon Medical School \\ ${ }^{2)}$ Department of Urology, Tokyo Medical School \\ ${ }^{3)}$ Mizumachi Clinic \\ ${ }^{4)}$ Department of Urology, Xi'an Jiaotong University
}

会員制クリニックの人間ドックで1993年から1998年の間に症状のない203名に前立腺癌検診を行い尿路感染症 を伴っていず血清PSA（前立腺特異抗原）值が高ったのは11名であった。そのうち患者の了承が得られて生検を 行ったのは 5 名で，うち 3 名（1.48\%）に前立腺癌を認め, 前立腺全摘除術の適応と診断し同手術を施行した。

メンバー退会のため 2 名が消息不明だが, 前立腺全摘除術を受けた 3 名は術後平均 7 年でPSA再発を含め再発 を認めず，残りの 6 名ではその後の健診でも前立腺癌は発見されていない。会員性クリックの役割はほとんどが 予防医学にあると思われるが, 今回の調查対象203名において前立腺癌に関しては, 少なくとも現時点では当クリ ニックの役割を果たせたと考えた。

索引用語：前立腺癌 (prostate cancer), 前立腺生検 (biopsy of the prostate), 前立腺癌検診 (screening for the prostate cancer)

\section{緒言}

今回の特集は前立腺癌の診断，治療における最 近の情報を中心に述べてもらった。では実際に診 療の現場ではどうであるかを症例は203名と少な くまた古い調査結果ではあるが，血清PSA（前立 腺特異抗原）による前立腺癌検診後もしくは前立 腺癌手術後 7 年以上を経過したデーターも含まれ ており，また論文未発表なので紹介することにし た。

\section{対象および方法}

当時当クリニックの会員数は約 500 名であった が，女性会員もいて，また当時PSA測定はドック でもオプションで, 1993年から1998の間に203名に おいてPSAが測定された。

PSAの測定法はこの調查期間の 5 年間に 4 回 変わっているが, 最終検査はTandem法で行われ, 正常値は $4.0 \mathrm{ng} / \mathrm{ml}$ であった。 


\section{成 績}

受診者の年齢分布は 30 歳代 21 人 (10.3\%)，40墄 代48人 $(23.6 \%) ， 50$ 歳代77八 $(37.9 \%) ， 60$ 歳代 47 人 (23.2\%)，70歳代 8 人 (3.9\%)，80歳代 2 人 (1.0\%) であった。

PSA值が異常值を示したのは203人中12人で, その内尿路感染症のため一過性に異常值を示した と思われた1名を除くと11人 (5.4\%) で，年齢別 では50歳代 77 人中 4 人 $(5.2 \%) ， 60$ 歳代 47 人中 5

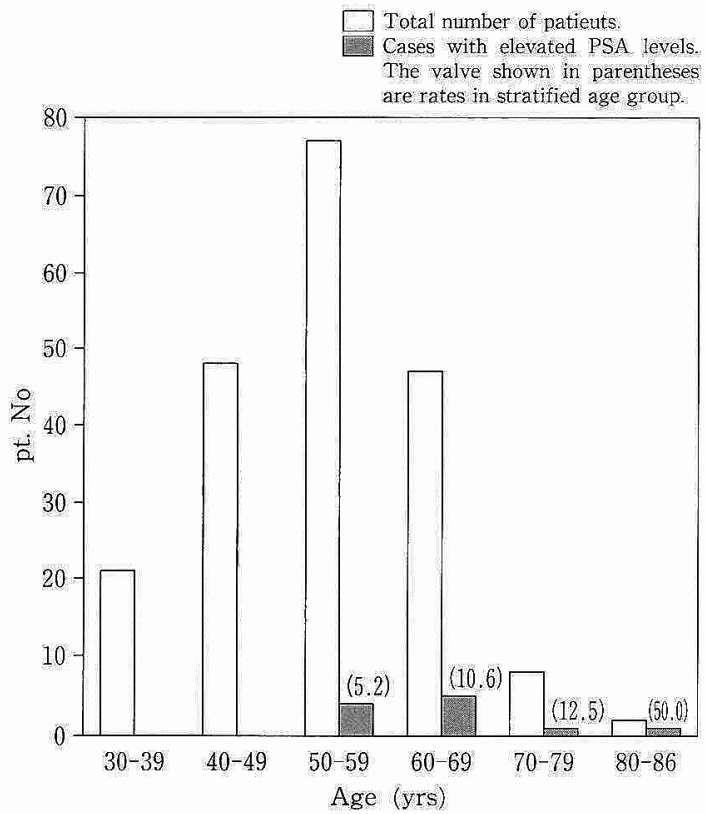

Figure Age distribution and number of case with elevated PSA levels.
人 $(10.6 \%), 70$ 歳代 8 人中 1 人 $(12.5 \%), 80$ 歳 代 2 人中 1 人 $(50.0 \%)$ であった (Figure)。

上記11名全例 (Table) で直腸診で異常老認めな かったが，うち前立腺生検の了解が得られた 5 人 で生檢を行ないCase 7，8，100 3 名で前立腺癌 が発見され前立腺全摘除術の適応と診断し同手術 を施行した。全摘組織における病理診断は 1 例が pT2a，2 例がpT2bで，その他の病理所見からも前 立腺全摘除術の適応であったことが確認された。 この 3 名は術後 $8 ， 7 ， 6$ 年が経過したが再発は 見られていない。前立腺生検を受け悪性所見が認 められなかったCase 4，9はPSA值2.0，6.2ng/ mlでPSA值は正常值に下降もしくはさらなる上 暑は見られていない。

生検を受けなかった 6 名のその後の経過は下記 の通りである。Case11の86歳の患者は 5 年後に循 環器疾患で死亡した。Case 1 は引き続きPSA12.5 $\mathrm{ng} / \mathrm{ml}$ 高值であるが 8 年の経過を考えると, PSA值のさらなる上昇はなく前立腺が当時でも $50 \mathrm{~g}$ と夫きかたのがPSA高值の原因と思われ る。Case 5，6はそれぞれPSA值3.2，3.0ng/ml と正常值である。Case 2，3は会員を退会され残 念ながら連絡がとれない。

203名のうち, 何年かにわたりドックを受けてい る間にPSA值が上昇したのはCase 4，6の2例で 初回は正常値であったが，それぞれ2，4年の間 に正常域を超之た。その他の症例は初回検查です でに高值であった。

Table Characteristics of 11 patients with elevated PSA.

\begin{tabular}{|c|c|c|c|c|c|}
\hline $\begin{array}{l}\text { Case } \\
\text { no. }\end{array}$ & $\begin{array}{l}\text { Age } \\
\text { (yrs) }\end{array}$ & $\begin{array}{c}\text { PSA } \\
(\mathrm{ng} / \mathrm{ml})\end{array}$ & $\begin{array}{l}\text { Result of } \\
\text { Biopsyof }\end{array}$ & Treatment & $\begin{array}{l}\text { Latest levels } \\
\text { PSA (ng/ml) }\end{array}$ \\
\hline 1 & 54 & 19.2 & NP & None & 12.6 \\
\hline 2 & 55 & 4.6 & NP & None & Lost for follow up \\
\hline 3 & 54 & 9.5 & $\mathrm{NP}$ & None & Lost for follow up \\
\hline 4 & 56 & 8.7 & Benign & None & 2.0 \\
\hline 5 & 62 & 4.4 & NP & None & 3.2 \\
\hline 6 & 65 & 5.3 & NP & None & 3.0 \\
\hline 7 & 60 & 6.8 & Malignant & Prostatectomy & less than 0.2 \\
\hline 8 & 69 & 9.2 & Malignant & Prostatectomy & less than 0.2 \\
\hline 9 & 60 & 10.2 & Benign & None & 6.2 \\
\hline 10 & 71 & 8.4 & Malignant & Prostatectomy & less than 0.2 \\
\hline 11 & 86 & 14.6 & NP & None & Died of other disease \\
\hline
\end{tabular}

NP : Not performed 


\section{5。会員性クリニックにおける前立腺癌検診の実際}

\section{考察}

今回報告した会員制クリニックのドックにおけ る前立腺癌検診のデータは, 幸いその後約 7 年の 経過も併せて報告できたのでその点古い調査結果 の発表でも許されると思うが，本来なら20世紀の 内に発表すべきものであった。その当時書き初め ていた文頭は下記のようなものであった。

『水町クリニックは社会で知名度が高い，もし くは各界のトップの患者が多く，医療のブティッ クとしての機能およびサービスを要求される。つ まりよい医療を待時間が最小限で受けられるこ と，またかなりの重要事項として「痛くない診察」 を目的として会員が来院する。例えば胃ファイ バーも短時間で痛くなく正確な診断が行われてい る。従って, 前立腺癌の精査も同様のことが要求 される。しかし, 胃ファイバーや大腸ファイバー と異なり経直腸的超音波 6 力所生検は世間にあま り普及していないので，患者が「本当にそれを受 けなくてはいけないのか」と疑問に思うことが少 なくない。その際は，医師が「本当にそれを受け なくてはいけない。」と自信をもって言うことが大 切である。』患者から前立腺生検の了解を得るこ とがやや困難な時代であったことがうかがえる。

ところが天皇陛下が前立腺癌の手術を受けられ るとの発表が2002年年末になされ 2003 年は多くの 人が前立腺癌検診に関心を持つようになり，泌尿 器科医は先に述べた患者への説得もやや容易とな るとともに, 診断, 治療に忙しい 1 年を過ごした。 2004年は全国的にも前立腺癌を一斉に刈り取った せいかやや暇であったが, 2005年 1 - 2 月は筆頭筆 者の大学では開腹 9 例, 腹腔鏡下 7 例, 計 16 例の 前立腺癌に対する全摘術が施行され，世間で言わ れている通り前立腺癌が増加の傾向にあることを 示している。以上当クリニックの特徵, 世の中の 風潮とその変遷を紹介した。

さてドックの前立腺癌検診の結果についてであ るが, 前立腺癌発見率 $1.48 \%$ は母集団の性質や生 検の適応がほぼ同様にもかかわらず，当時の他施
設のそれに比しやや高率である。倉敷市 ${ }^{1)}$, 福岡

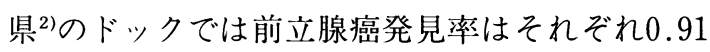
\%，0.08\%であった。筆者らのドックでより高率 であったのは，本特集の診断の項で紹介した木村 らの生検方法を用いたわけではないので, 生検の 技術が優れていたわけではない。推論に過ぎない が，一般に言われているように多忙な政財界の要 人に前立腺癌が多いのかも知れない。

今回は一般に行われている自治体の前立腺癌検 診と異なり, 特殊な集団での調査結果であったが, ここでも検診が有用であった。欧米では前立腺癌 が男性癌死亡者率の約20\%を占めているが，わが 国では，まだ $3 \%$ 強にしか過ぎないとのことで3), 今後さらなる前立腺癌の増加が予測されるが, ど のような集団であろうとも前立腺癌検診はますま す重要視されることになろう。

\section{おわりに}

ある会員制クリニックにおける1993年から1998 年にかけての前立腺癌検診を, 社会の風潮の変遷 も含め紹介した。今回対象となった 203 名における 前立腺癌の発見率は高いものの子後はよく, PSA を用いた前立腺癌検診の有用性が再確認された。 また会員制クリックの役割はほとんどが予防医学 にあると思われるが，少なくとも現時点では当ク リニックの役割を果たせたと考えた。

今後さらなる前立腺癌の増加が予測されるが, 検診対象がどのような集団であろうとも前立腺癌 検診はますます重要となってくるであろう。

\section{参考文献}

1）松田陽介，寺田直樹，前川信也他：人間ドック PSA前立腺癌検診における成績. 腎泌予防医誌 $8: 30-32,2000$

2）古賀寛史，内藤誠二，尾本徽男他：福岡県におけ るドック前立腺癌検診の現状一第 2 報一. 腎泌予 防医誌 $8: 33-35,2000$

3）川島英敏，三原修一，北川淳一他：PSAによる前 立腺がん検診の評価. 腎泌予防医誌 $8: 36-38$, 2000 